\title{
GUEST-TECHNOLOGY AS MEANS OF ACTIVATION COGNITIVE ACTIVITY OF JUNIOR SCHOOLCHILDREN
}

\author{
КВЕСТ-ТЕХНОЛОГІЇ ЯК ЗАСІБ АКТИВІЗАЦІї \\ ПІЗНАВАЛЬНОЇ ДІЯЛЬНОСТІ МОЛОДШИХ ШКОЛЯРІВ
}

\author{
Olga POPOVA, \\ candidate of pedagogical sciences, \\ Ольга ПоповА, \\ associate professor \\ https://orcid.org/0000-0002-4338-592X \\ poi2009bam@ukr.net \\ Larisa POPOVA, \\ candidate of philological sciences, \\ associate professor \\ plarp29@ukr.net \\ Berdiansk state pedagogical \\ university \\ 4 Schmidta St.,Berdiansk, \\ Zaporizhzhia region, 71100 \\ Лариса ПОПОВА, \\ кандидат філологічних наук, \\ доцент \\ Бердянський державний \\ педагогічний університет \\ $\triangle$ вул. Шмідта, 4 \\ м. Бердянськ, Запорізька обл.
}

Original manuscript received: October 16, 2019

Revised manuscript accepted: December 19, 2019

\section{ABSCTACT}

In the article the problem of the use of quest-technology on the lessons of literary educational industry at initial school with the aim of activation of cognitive activity of students is examined. A concept "quest", essence of this technology, primary purposes, opens up, educational effects from application on the lessons of Ukrainian and literary reading; presented structure of realization of quest; efficiency of the use is grounded in an educational process. As a conclusion, quest -technology will assist creation of variety forms of educational process at modern initial school, will create terms for productive cognitive activity of every bread-winner of education taking into account interests and capabilities; will explain and activate all spheres of development of personality, form ability to study, and help a modern teacher to step back from the usual stereotypes of organization of lesson. Among advantages of application of quest there is that he will provide the rational informative filling, combination of collective work of class from educational process at modern initial school, will create terms for productive cognitive activity of every bread-winner of education taking into account interests and capabilities; will explain and activate all spheres of development of personality, form ability to study, and help a modern teacher to step back from the usual stereotypes of organization of lesson. Among advantages of application of quest there is that he will provide the rational informative filling, combination of collective work of class with individual activity of students.

Key words: playing technologies, quest-technology, junior schoolchildren, cognitive activity 
Постановка проблеми. Одним із головних пріоритетів, що визначає траєкторію розвитку вітчизняної освіти загалом і початкової зокрема $є$ створення інноваційного середовища, у якому здобувачі опановують уміння самостійного засвоєння знань протягом життя та їх застосування в практичній діяльності. У сучасних умовах якість початкової освіти пов'язується з реалізацією компетентнісного підходу, який спрямований на формування в учнів ключових і предметних компетентностей. Саме це зумовлює практичну зорієнтованість навчання, створення передумов для поетапного управління формуванням навчальних досягнень учнів, підвищенням особистої відповідальності усіх учасників освітнього процесу за якість навчальних досягнень. Нові підходи актуалізують проблему «як вчитися учневі», тобто в якій формі відбуватиметься освітня діяльність, як організувати її вчителеві, щоб досягти найвищих результатів. Актуальність та затребуваність нетрадиційних уроків в Новій українській школі зв'язана 3 необхідністю формування предметних та метапредметних компетентностей, серед яких ключовими $€$ пізнавальні, комунікативні, регулятивні та особистісні.

На думку багатьох науковців (О.Ільченко, О. Мішагіна, І. Сокол та ін.), інноваційні технології, з поміж яких виокремлюємо квест-технології, $€$ ефективним засобом активізації пізнавальних інтересів, навчальної мотивації, мисленнєвої діяльності, комунікативної компетентності учнів, що дає змогу оволодіти не тільки предметними, а й надпредметними знаннями та вміннями.

Мета статті - узагальнити теоретичні підходи до застосування квест-технологій в освітньому процесі початкової школи та розкрити ефективність їх у практичній діяльності учнів.

Методи та методика дослідження: теоретичні (аналіз, узагальнення, систематизація наукових джерел під кутом зору досліджуваної проблеми); емпіричні (експеримент з метою активізації пізнавальної діяльності здобувачів початкової освіти).

Результати та дискусії. У вітчизняному науковому просторі до сучасного уроку в початковій школі ставиться багато вимог, головною 3 яких $€$ те, що здобувачі освіти є активними його учасниками. Психологи і педагоги (Н. Бібік, П. Блонський, Л. Виготський, Д. Ельконін, Г. Костюк, О. Леонтьєв, О. Савченко В. Сухомлинський, К. Ушинський та ін.) довели, що молодші школярі під час різних видів ігор краще засвоюють навчальну інформацію. Від правильності їх організації залежатиме обсяг, глибина, міцність і усвідомленість засвоєних знань учнями, умінь, навичок, компетенцій; розвиток їхньої активності, самостійності та творчого ставлення до діяльності.

Різним аспектам дослідження проблеми впровадження квесттехнології в освітній процес приділяли увагу О. Багузіна, Я. Биховський, Г. Воробйов, О. Гапеєва, Д. Грабчак, М. Гриневич, Л. Желізняк, В. Заводнюк, Л. Іванова, С. Іць, Н. Кононець, Т. Кузнецова, О. Китманова, А. Статкевич, С. Напалков, О. Нечитайлова, Н. Цодікова, Г. Шаматонова, О. Шевцова, В. Шмідт, О. Шульгіна та інші. 
Зважаючи на універсальність квест-технології, ї̈ намагаються впроваджувати педагоги закладів загальної середньої освіти, оскільки вона завжди $\epsilon$ ефективною, повноцінно забезпечує умови для індивідуального розвитку й реалізації здібностей учнів, досягнення навчальних результатів високого рівня, набуття навичок міжособистісного спілкування і взаємодії у спільній справі.

Квест (від англ. quest - пошук i adventure - пригода) - це командна пригодницька гра, у якій учасники мають виконати завдання відповідно до сюжету [1]. Причому, саме правильність відповідей визначає подальший напрямок або є ключем, підказкою, якими можна скористатися на шляху до фріналу. Квест-технологію можна застосовувати на всіх без винятку уроках початкової школи, зокрема змоделювати урок, його частину або систему уроків, та в позаурочній діяльності.

Квест-технології в навчанні та вихованні школярів почали застосовуватися Берні Доджом та Томом Марчем з університету СанДієго з 1995 року як складники пошукової системи, у якій передбачалося поетапне виконання завдання.

Вітчизняні дослідження цієї технології стосувалися зокрема спроби класифікувати квести за різними критеріями (формою та режимом проведення; за терміном реалізації, формою та предметним змістом; структурою сюжетів; інформаційним освітнім середовищем; технічною платфрормою; діяльністю учнів, характером контактів; типом завдань) (Сокол І., 2014).

Аналіз психолого-педагогічної літератури з проблем застосування інноваційних технологій дозволив визначити основні цілі квестів у початковій школі: сприяти розвитку комунікативної взаємодії між гравцями, що $\epsilon$ засобом їх згуртування; спонукати учасників до критичного опрацювання інформації, розвивати їх пізнавальну активність, уміння узгоджувати свої дії з діями інших; сприяти прояву дослідницької активності учнів у процесі вирішення завдань різних видів і пошуку результату оригінальними діями; самостійно приймати рішення, брати на себе відповідальність за їх реалізацію; виховувати впевненість, культуру спілкування, доброзичливість, емоційність.

Під час проєктування квесту учителеві початкової школи треба врахувати, що залежно від сюжету вони можуть бути: лінійними, коли гравці, виконавши одне завдання, отримують наступне, і так продовжується до кінця маршруту; штурмовими, де всі учасники мають основне завдання та перелік місць з підказками, але при цьому самостійно обирають шляхи виконання завдань; кільцевими, які нагадують "лінійний" квест, але команди стартують з різних точок, які будуть для них фінішними.

Як свідчать наукові джерела, квести допомагають молодшим школярам добре справлятися з вимогами працювати в команді, зокрема налагоджувати успішну взаємодію з їі учасниками; відчути та сформувати взаємодопомогу; здійснити правильний розподіл обов'язків; за 
Серія: Педагогічні науки. - Вип.3. - Бердянськ : БДПУ, 2019. - 453 с.

необхідності мобілізуватися та швидко вирішувати нестандартні завдання, з якими в звичайному житті вони не зустрічалися.

Оскільки учні початкової школи досить активно працюють 3 комп'ютером, педагог може обрати веб-формат або реал-квести («жива» форма). Слід мати на увазі, що під час квесту учні можуть стикатися 3 різними завданнями; від них вимагається уміння здійснювати пошук та аналіз інформації; її обробку, здатність порівнювати, синтезувати й ділитися узагальненнями 3 іншими учасниками. Виконуючи квестзавдання, молодші школярі вчаться формулювати проблему, планувати свою діяльність, критично мислити, вирішувати складні завдання, порівнювати альтернативні думки, самостійно приймати продумані рішення, брати на себе відповідальність за їх реалізацію.

До освітніх ефектів застосування квестів на уроках української мови та літературного читання можна віднести такі: значний рівень пізнавальної активності здобувачів початкової освіти; підвищення їхньої мотивації до вивчення предметів мовно-літературної освітньої галузі; наявність елементів діалогового навчання; встановлення зв'язку нового матеріалу 3 уже засвоєним; формування здібностей до самостійної освітньої діяльності та вибору засобу рішення навчально-ігрових завдань; можливість роботи на загальний командний результат; здатність спостерігати за своїми діями та діями інших учасників гри, самоаналіз виконаних завдань.

Квест дозволяє застосовувати різні стратегії розвитку дітей, за допомогою впливу на такі види розумової діяльності: спогади відновлення в пам'яті фактів, понять; відтворення - дія за поданим алгоритмом; обгрунтування - зв'язок окремого випадку з загальним принципом або поняттям; реорганізація - перенесення знань у нові ситуації, винайдення оригінального рішення проблем; співвіднесення зв'язок нових знань з отриманими раніше; рефлексія.

Як свідчать результати практичного впровадження квесттехнологій, краще працювати невеликими групами (по 4-6 учнів), що забезпечує можливість урахування їх вікових особливостей. У такому освітньому середовищі молодші школярі почуваються більш упевненими і розвивають такі особистісні якості, як здатність до співробітництва, почуття лідерства та відповідальність за рішення групи.

Слід зауважити, що вчитель початкової школи під час проєктування такого уроку має визначити, які здібності та навички розвиватимуться або вдосконалюватимуться під час проведення квесту. Крім того, слід підготувати цікаві завдання, скласти план роботи, список інформаційних ресурсів тощо. Варто пам'ятати, що педагог $€$ певним зразком мовленнєвої поведінки, тому як керівник цієї гри він повинен доступно пояснити мету, завдання, етапи та правила квесту, організувати спілкування молодших школярів, беручи до уваги при цьому їхні особистісні якості.

Без урахування освітніх галузей уроки (заняття) в Новій українській школі з використанням квест-технології чітко структуровані:

1. Оголошення теми квесту. Учні знайомляться з умовами організації гри, фрормують самостійно або за допомогою вчителя 
команди, вибирають певні ролі (наприклад, майстер з частин мови, знавець правильної вимови тощо), формулюють мету за допомогою певних підказок (предмети, запитання вчителя).

2. Мотивація.

3. Планування. Залежно від теми та мети уроку учні самостійно визначають хід дій для досягнення необхідного результату.

4. Практична діяльність учасників квесту. Гравці виконують низку завдань, заздалегідь підготовлених педагогом.

5. Контроль за перебігом гри. За її правилами при неправильному виконанні одного завдання перехід до наступного блокується, що спонукає учасників відшукати помилку й спробувати самостійно її виправити.

6. Здійснення корекції. Учасники повертаються до попереднього завдання, вносять корекцію та йдуть далі.

7. Оцінювання дій учасників. Учні коментують результати гри. Оцінка дається не тільки діям усієї команди, але й окремим її учасникам.

8. Підсумок квесту. Проводиться рефлексія, здійснюється планування подальших дій.

Ми вважаємо, що в Новій українській школі можна досить ефективно застосовувати квест-технологію на уроках літературного читання, зокрема, поділити учнів на групи за допомогою пазлів.

Наведемо приклад застосування квест-технодлогії.

Тема уроку "У світі казок".

Учитель вирушає з молодшими школярами та казковими героями в мандри. Особливістю квесту є наявність заплутаного сюжету, загадка, пошук "скарбів", рятування персонажа або якась інша франтастична діяльність.

У нашому випадку квест починався з пригоди: чарівники запросили на зустріч героїв різних казок, але почався сильний буревій. Завдання учасників полягало в тому, щоб допомогти героям повернутися до своїх казок.

Молодші школярі отримали маршрутні листи, у яких чітко визначені завдання. Причому, пізнавальні інтереси розвивала саме їх різноплановість: аудіо та відеозаписи, декламація, пазли, друдли та ін. Виконання певного завдання допомагало герою та надавало можливість отримати бали. Групи починали виконувати завдання, кожне з яких було логічним продовженням попереднього. Наприклад, у кросворді зашифрована назва книги, що лежить на полиці в класі, а в ній зображений ребус, який допоможе знайти лист, написаний героями, що знаходилися в небезпеці. Цікавим завданням $€$ порівняння анотацій казок та обкладинок книг.

У процесі захисту виконаних завдань квест-технології учні переконувалися, що, по-перше, виконати завдання можна по-різному, що активізувало пізнавальну самостійність кожного учасника безпосередньо та групу загалом; по-друге, урахування інтересів і думок інших впливало на досягнутий результат. Крім того, досліджувана технологія сприяє формуванню в здобувачів початкової освіти інформаційних компетентностей, знань та вмінь, які виховують самоповагу та емоційно позитивне ставлення до себе; цілеспрямованість, наполегливість у 
досягненні мети.

Висновки. Таким чином, квест-технологія буде сприяти урізноманітненню форм освітнього процесу в сучасній початковій школі, створюватиме умови для продуктивної пізнавальної діяльності кожного здобувача освіти з урахуванням інтересів і здібностей; мотивуватиме й активізуватиме всі сфери розвитку особистості, формуватиме вміння вчитися, а значить допоможе сучасному педагогові відійти від звичних стереотипів організації уроку. Серед переваг застосування квесту $є$ те, що він забезпечить раціональне інформаційне наповнення, поєднання колективної роботи класу з індивідуальною діяльністю учнів.

\section{Література}

1. Бібік Н. М., Вашуленко М.С., Мартиненко В.О. Формування предметних компетентностей в учнів початкової школи: монографія. Київ: Педагогічна думка, 2014. $346 \mathrm{c}$.

2. Журба К., Шкільна І. Квест як засіб формування національно-культурної ідентичності підлітків. Рідна школа. 2017. № 11. С. 44-51.

3. Ільченко О. В. Використання web-квестів у навчально-виховному процесі. [Електронний ресурс]. - Режим доступу: http://osvita.ua/school/lessons summary/proftech/32834/

4. Концепція Нової української школи. URL: [Електронний ресурс]. Режим доступу: https://www.kmu.gov.ua/storage/app/media/reforms/ukrainska-shkolacompressed.pdf

5. Мішагіна О. Д. Використання квесту як засобу активізації навчальної діяльності учнів [Електронний ресурс]. - Режим доступу: http://ru.osvita.ua/school/lessons summary/edu technology/34730/

6. Організаційні форми навчання у початковій школі: посібник / О. Я. Савченко, Н. М. Бібік, В. О. Мартиненко та ін. Київ : Видавничий дім «Сам», 2017. $304 \mathrm{c}$.

7. Сокол І. М. Квест як сучасна інноваційна технологія навчання. Оновлення змісту, форм та методів навчання і виховання в закладах освіти : зб. наук. пр. Рівне : РДГУ, 2013. Вип. 7 (50). С. 168-171.

8. Сокол І. М. Класифрікація квестів. Педагогіка формування творчої особистості у вищій і загальноосвітній школах. 2014. Випуск 36 (89). С. 369-374.

\section{References}

1.Bibik N. M., Vashulenko M.S., Martynenko V.O. Formuvannia predmetnykh kompetentnostei v uchniv pochatkovoi shkoly: monohrafiia. Kyiv: Pedahohichna dumka, 2014. 346 s.

2.Zhurba K., Shkilna I. Kvest yak zasib formuvannia natsionalno-kulturnoi identychnosti pidlitkiv. Ridna shkola. 2017. № 11. S. 44-51.

3. Ilchenko O. V. Vykorystannia web-kvestiv u navchalno-vykhovnomu protsesi. [Elektronnyi resurs]. $\quad$ Rezhym dostupu: http://osvita.ua/school/lessons_summary/proftech/32834/

4.Kontseptsiia Novoi ukrainskoi shkoly. URL: [Elektronnyi resurs]. - Rezhym dostupu: https://www.kmu.gov.ua/storage/app/media/reforms/ukrainska-shkolacompressed.pdf

5. Mishahina O. D. Vykorystannia kvestu yak zasobu aktyvizatsii navchalnoi diialnosti uchniv [Elektronnyi resurs]. - Rezhym dostupu: http://ru.osvita.ua/school/lessons_summary/edu_technology/34730/ 
6.Orhanizatsiini formy navchannia u pochatkovii shkoli: posibnyk / O. Ya. Savchenko, N. M. Bibik, V. O. Martynenko ta in. Kyiv : Vydavnychyi dim «Sam», 2017. $304 \mathrm{~s}$.

7.Sokol I. M. Kvest yak suchasna innovatsiina tekhnolohiia navchannia. Onovlennia zmistu, form ta metodiv navchannia i vykhovannia $v$ zakladakh osvity : zb. nauk. pr. Rivne : RDHU, 2013. Vyp. 7 (50). S. 168-171.

8.Sokol I. M. Klasyfikatsiia kvestiv. Pedahohika formuvannia tvorchoi osobystosti u vyshchii i zahalnoosvitnii shkolakh. 2014. Vypusk 36 (89). S. 369-374.

\begin{abstract}
АНОТАЦІЯ
У статті розглядається проблема використання квест-технології на уроках мовно-літературної освітньої галузі в початковій школі з метою активізації пізнавальної діяльності учнів. Розкривається поняття «квест», сутність цієї технології, основні цілі, освітні ефекти від застосування на уроках української мови та літературного читання; представлена структура проведення квестів; обгрунтовується ефективність використання в освітньому процесі. Як висновок, квест-технологія буде сприяти урізноманітненню фрорм освітнього процесу в сучасній початковій школі, створюватиме умови для продуктивної пізнавальної діяльності кожного здобувача освіти з урахуванням інтересів і здібностей; мотивуватиме й активізуватиме всі сфрери розвитку особистості, формуватиме вміння вчитися, а значить допоможе сучасному педагогові відійти від звичних стереотипів організації уроку. Серед переваг застосування квесту є те, що він забезпечить раціональне інформаційне наповнення, поєднання колективної роботи класу з індивідуальною діяльністю учнів.

Ключові слова: ігрові технології, квест-технологія, молодші школярі, пізнавальна діяльність, проєктування.
\end{abstract}

